\title{
Levels of selected heavy metals in soil, tomatoes and selected vegetables from Lushoto district-Tanzania
}

\author{
Lugwisha Esther Hellen*, Othman Chande Othman \\ University of Dar es Salaam, Chemistry Department, P. O. Box 35061, Dar es Salaam, Tanzania
}

Email address:

elugwisha@gmail.com (Lugwisha E. H.),o_chande@yahoo.co.uk (Othman, O. C.)

To cite this article:

Lugwisha Esther Hellen, Othman Chande Othman. Levels of Selected Heavy Metals in Soil, Tomatoes and Selected Vegetables from Lushoto District-Tanzania. International Journal of Environmental Monitoring and Analysis. Vol. 2, No. 6, 2014, pp. 313-319.

doi: 10.11648/j.ijema.20140206.13

\begin{abstract}
This study involved the determination of heavy metals of $\mathrm{Cd}, \mathrm{Cr}, \mathrm{Cu}, \mathrm{Pb}$ and $\mathrm{Zn}$ in cauliflower (Brassica oleracea $\mathrm{L}$. var botrytis L.), carrot root (Daucus carota L.), tomato fruit (Lycopersicum esculentum Mill.), onion bulb (Allium cepa L.) and leafy cabbage (Brassica oleracea L. var capitata L.) and the respective soils from Lushoto District, Tanzania. Samples were collected from eight growing sites. The accumulated heavy metals were quantified and the levels compared to the FAO/WHO CODEX-STAN 179:2003 and TZS 972:2007 contamination limits for such produce. The methodology involved random sampling, extraction of the metals from the vegetable and soil and determination of heavy metals by using ICP-OES and GFAAS. The levels of $\mathrm{Cu}$ in all vegetables were below the FAO/WHO limit while levels of $\mathrm{Cr}$ and $\mathrm{Zn}$ in all vegetables were found to be above this limit therefore advocating a health risk for consumers. Pb was only found in carrots at 2 sites (Montisory and Resource centre) and in onions at the market all at levels above the FAO/WHO limit while $\mathrm{Cd}$ was only found in onions and tomatoes at 2 sites (market and Montisory) at above the FAO/WHO limits. Vegetables especially onions from the Mlalo market advocate a health risk to consumers. Levels of heavy metals in the soils were below the limits of the Tanzanian standard (TZS 972: 2007) and were lower than levels found in vegetables. However, the bioconcentration factor for $\mathrm{Cr}, \mathrm{Pb}, \mathrm{Cd}$ and $\mathrm{Zn}$ in all vegetables and tomatoes where they were detected except for cabbages at the Garage site were found to be above 1, an indication of high uptake of heavy metals in the vegetables from the soil. $\mathrm{Cu}$ at $80 \%$ of the sites had a BCF lower than 1 indicating that $\mathrm{Cu}$ was more abundant in the soil compared to the vegetables. These results suggest that these vegetables from Lushoto district are not safe for consumption in their raw state.
\end{abstract}

Keywords: Heavy metals, Vegetables, Tomatoes, Soil, Bioconcentration factor

\section{Introduction}

Pollution of foods by heavy metals is a worldwide phenomenon. Studies have revealed that fruits and leafy vegetables are vulnerable to heavy metal contamination from soil, wastewater and air pollution [1]. The toxicity and consequent threat to human health by heavy metals such as cadmium $(\mathrm{Cd})$, copper $(\mathrm{Cu})$, lead $(\mathrm{Pb})$, chromium $(\mathrm{Cr})$, zinc $(\mathrm{Zn})$, Nickel (Ni), Arsenic (As), cobalt (Co) and mercury (Hg) are a function of concentration and bioaccumulation [1]. These elements are serious stressors to the environment, representing significant human effects via food chains, water and air pollution [2].

Growing awareness about sustainable agriculture and health risks associated with agrochemicals and human activities has brought a major shift in people's preference towards food safety and quality of fruits, vegetables and other foods [3]. The consumers' concern over food safety and quality arises from globalization of trade in food and intensive agricultural pollution arising from both natural (geological) and anthropogenic activities (mechanization and agrochemicals application). Heavy metals are non-biodegradable and bioaccumulate in living tissues through the food chain. This fact necessitates for frequent determination of heavy metals in vegetables and soil for the safety of consumers. Fruits, vegetables and other foods are among pathways by which heavy metals enter the human tissues leading to deterioration of health [4].

Tanzania has several regions where fruits, vegetables and other horticultural products are grown. These regions among others include Lushoto, Iringa, Mbeya, Morogoro, Kilimanjaro and Arusha [5, 6]. Lushoto district is well 
known for the growing of tomatoes and green vegetables throughout the year. These fruits and vegetables are sold through different chains of markets, from local villages, regional to national markets and supermarkets while others are exported to neighboring countries [6].

Several studies conducted in Dar es Salaam, Tanzania, on heavy metals in fruits, vegetables and soils have indicated the presence of heavy metal contamination at different concentrations [7-11]. A similar study was conducted in Morogoro for pumpkin and chinese cabbage by Chove et al. [12]. Determination of heavy metals in edible portions of amaranth (Amaranthus viridis), chinese cabbage (Brassica chinensis), cowpea leaves (Vigna unguiculata), leafy cabbage (Brassica oleracea var. capitata) and pumpkin leaves (Cucurbita moschata) in Dar es Salaam has shown the presence of $\mathrm{Cd}, \mathrm{Ni}, \mathrm{Pb}, \mathrm{Cr}, \mathrm{Cu}$ and $\mathrm{Zn}[13]$. A direct correlation between $\mathrm{Zn}$ and $\mathrm{Pb}$ levels in soils with the levels in vegetables was also observed [8]. Consuming such vegetables may lead to severe health problems, such as acute/chronic chemical poisoning of body tissues. This observation triggered a need for this study on the determination of heavy metal contamination in cauliflower (Brassica oleracea var. botrytis L.), carrot root (Daucus carota L.), tomato fruit (Lycopersicum esculentum Mill.), onion bulb (Allium cepa L.) and leafy cabbage (Brassica oleracea var. capitata L.) and the respective soils from Lushoto District, Tanzania.

\section{Material and Methods}

Table 1. Locations, soil pH, and samples from Lushoto District, Tanzania

\begin{tabular}{|c|c|c|c|}
\hline Location & Soil pH & Sample name & Scientific name \\
\hline Garage & 6.01 & Cabbages & $\begin{array}{l}\text { Brassica oleracea L. var. } \\
\text { capitata L. }\end{array}$ \\
\hline Kwekangaga & NA & Cabbages & $\begin{array}{l}\text { Brassica oleracea L. var. } \\
\text { capitata L. }\end{array}$ \\
\hline Kwekangaga & 6.30 & Cauliflowers & $\begin{array}{l}\text { Brassica oleracea L. var. } \\
\text { butrytis L. }\end{array}$ \\
\hline Kwekangaga & 6.30 & Tomatoes & $\begin{array}{l}\text { Lycopersicum esculentum } \\
\text { Mill. }\end{array}$ \\
\hline Lukozi-Jegeta & 6.57 & Cauliflowers & $\begin{array}{l}\text { Brassica oleracea L. var. } \\
\text { butrytis L. }\end{array}$ \\
\hline Lukozo-Jegeta & 6.06 & Cabbages & $\begin{array}{l}\text { Brassica oleracea L. var. } \\
\text { capitata L. }\end{array}$ \\
\hline Lukozi & 7.21 & Tomatoes & $\begin{array}{l}\text { Lycopersicum esculentum } \\
\text { Mill. }\end{array}$ \\
\hline Montisory-Sisters & 7.11 & Carrots & Daucus carota L. \\
\hline Mlalo market* & NA & Onion & Allium cepa L. \\
\hline Resource Centre & 5.65 & Carrots & Daucus carota L. \\
\hline Resource Centre & 5.65 & Cauliflowers & $\begin{array}{l}\text { Brassica oleracea L. var. } \\
\text { butrytis L. }\end{array}$ \\
\hline Montisory & 7.12 & Tomatoes & $\begin{array}{l}\text { Lycopersicon esculentum } \\
\text { Mill. }\end{array}$ \\
\hline
\end{tabular}

*Soil sample was not collected as samples were collected from the market
Samples of tomatoes, cauliflowers, cabbages, carrots and onions and of their respective soils were collected from 12 different locations in Lushoto district. The samples and locations are presented in Table 1. Two kilograms of each sample of tomatoes, cauliflower, carrots, onions and cabbages were randomly collected at each site to obtain representative samples. They were wrapped in pre-cleaned aluminum foil, packed in polyethylene bags and transported to Chemistry Department, University of Dar es Salaam for pre-treatment. Simultaneously, soil was sampled from the same locations of vegetable collection from a depth of 2 to $15 \mathrm{~cm}$ by using a non-steel sampler (scoop sampling). Samples were stored in sealed pre-cleaned polyethylene bags and transported to the Chemistry Department for pretreatment and analysis.

\subsection{Sample Preparation}

\subsubsection{Vegetable Samples}

For collection of vegetable samples, the method used by Chove et al. [12] was followed with minor modifications. The collected vegetables were washed thoroughly with fresh tap water and rinsed three times with distilled water to remove surface pollutants and any items adhering to the surfaces. Samples were sliced into small pieces and open air dried on paper for about 2 hours to eliminate excess moisture. Each sample was weighed, dried in an oven at $80{ }^{\circ} \mathrm{C}$ for several hours and reweighed to constant weight. The dried sample was ground in a mortar until it could pass through a $2 \mathrm{~mm}$ mesh sieve and stored in clean and dry polyethylene bags.

\subsubsection{Soil Sample Extracts}

Larger particles of soil were manually sorted out. The soil was then air dried, ground, and sieved. About $5.0 \mathrm{~g}$ soil was weighed by using a digital weighing balance and placed in a flask. $20 \mathrm{~mL}$ of extracting acid solution $(0.05 \mathrm{~N} \mathrm{HCl}+0.025 \mathrm{~N}$ $\mathrm{H}_{2} \mathrm{SO}_{4}$ ) was added to the sample. The mixture was placed on a mechanical shaker and shaken for 15 minutes. Filtration was then carried out through a Whatman filter paper No.42 into a $50 \mathrm{~mL}$ volumetric flask. The filter paper was washed with distilled water and washings collected into the same $50 \mathrm{~mL}$ flask. The solution in the flask was then diluted to $50 \mathrm{~mL}$ with distilled water. This solution was used for determination of levels of soil parameters [8].

\subsubsection{Sample Digestion - Dry Ashing}

About $2 \mathrm{~g}$ of ground vegetables were placed in a clean porcelain crucible and kept in a cool muffle furnace. The sample was then ashed at $450-500{ }^{\circ} \mathrm{C}$ overnight (12 hours). The ashed sample was cooled to room temperature in a desiccator. The ash was then dissolved in $5 \mathrm{~mL}$ of $20 \%(\mathrm{v} / \mathrm{v})$ hydrochloric acid. The solution was warmed slowly to dissolve any residues. Filtering of solution was carried out through an acid-washed Whatman filter paper No 42 into a 50 $\mathrm{mL}$ volumetric flask. The filter paper was washed with distilled water and washings collected in the volumetric flask. The resulting solution was diluted to the mark with distilled water, well mixed and used for determination of the heavy metals in vegetable samples [8]. 


\subsection{Determination of Soil $\mathrm{pH}$}

The determination of soil $\mathrm{pH}$ involved the use of the pH-meter (RS Components Ltd, stock No 610-540, serial No.082316, UK) with a combined glass electrode. The $\mathrm{pH}$ meter was calibrated over the appropriate range using standard buffer solutions of $\mathrm{pH} 4$ and $\mathrm{pH}$ 7. Adjustment was done for temperature and potential required by the instrument.

About $5 \mathrm{~g}$ of each sieved soil sample was accurately weighed using the digital weighing balance (Mettler Toledo model B 301-S, Switzerland) and put in a beaker. $50 \mathrm{~mL}$ distilled water was added to the sample [14]. The mixture was stirred vigorously for 15 seconds in a mechanical shaker and left to stand for 30 minutes. The electrode, removed from the buffer solution, was rinsed in the sample and placed in the slurry and swirled carefully. The $\mathrm{pH}$ values were then recorded after each reading had stabilized. The electrode was always rinsed with distilled water between successive measurements.

\subsection{Determination of Heavy Metals}

Determination of heavy metals from the filtrate of vegetables and soil samples were carried out by using the GFAAS (Analytik Jena AG/Konrad-Zuse-Straße 1/07745/Germany) for $\mathrm{Cu}$ and ICP-OES (Ultma2, HORIBA Jobin Yvon S.A.S, version 3, 2001, France) for $\mathrm{Cd}, \mathrm{Cr}, \mathrm{Pb}$ and $\mathrm{Zn}$. The analytical procedure is as described in [8].

\subsection{Quality Assurance}

Quality control tests were conducted on soil and vegetable samples in order to evaluate the experimental procedures and efficiency of the GFAAS and ICP-OES methods. The quality assurances was done by spiking each of the pre-digested samples of vegetable and soil with diluted solution of heavy metals standard solution $(20 \mu \mathrm{g} / \mathrm{kg}$ of $\mathrm{Cd}, \mathrm{Cr}, \mathrm{C}, \mathrm{Pb}$, and $\mathrm{Zn})$ prepared from several dilution of the $1000 \mu \mathrm{g} / \mathrm{g}$ stock standard solution. The spiked samples were then digested and extracted using the same procedure as that of soil and vegetable samples.

\subsection{Statistical Analysis}

Unpaired student's t-test was used to determine and compare the statistical differences between the mean concentrations of two groups of samples. A probability level of $\mathrm{P}<0.05$ was considered statistically significant. The analysis was performed by feeding the raw data into a special program for unpaired student's t-test determination as described by Kothari [15].

\subsection{Bioconcentration Factor (BCF)}

The transfer of trace elements from soil to plant edible parts is best described by considering the bioconcentration factor. $\mathrm{BCF}$ is calculated as the ratio of the concentration of heavy metals in the vegetables to that in the corresponding soil where vegetables were obtained, all based on (dry weight) for each vegetable separately.
The bioconcentration factor $=[\mathrm{M}]_{\text {plant }} /[\mathrm{M}]_{\text {soil }}$ where $[\mathrm{M}]_{\text {plant }}$ and $[\mathrm{M}]_{\text {soil }}$ represent the heavy metal concentration in extracts of plants and soils on a dry weight basis respectively.

\section{Results and Discussion}

\subsection{Soil pH}

The $\mathrm{pH}$ of the soils from the investigated locations are presented in Table 1. Soil $\mathrm{pH}$ had a narrow range between mildly acidic $(\mathrm{pH} 5.65)$ at the Resource centre and nearly neutral (pH 7.21) at Lukozi, with a mean $\mathrm{pH}$ of $6.40 \pm 0.59$ (i.e. $6.40 \pm$ Std. Deviation). A trend in soil $\mathrm{pH}$ of Resource centre $<$ Garage < Lukozi-Jegeta (cabbage) < Kwekangaga < Lukozi-Jegeta (cauliflowers) $<$ Montisory $<$ Lukozi (tomatoes) was observed. Akinola et al. [14] recorded a pH of 6.02 for soil from a non-industrial area and concluded that soils with near neutral $\mathrm{pH}$ cause low uptake of heavy metals by vegetables, thereby leaving a higher concentration of the metals in the soil. In our study, it was observed that where soil $\mathrm{pH}$ was recorded near neutral ( $\mathrm{pH} 7.11)$, low concentration of heavy metals were recorded in the vegetables than in soil except for $\mathrm{Pb}$. This high $\mathrm{Pb}$ might be due to vegetables absorbing heavy metals through leaves exposed to air from polluted environment [12].

\subsection{Concentrations of Heavy Metals in Vegetables, Tomatoes and Soils}

\subsubsection{Cadmium}

It has been reported that increases in soil $\mathrm{Cd}$ content will result in an increased uptake by vegetables [16]. The $\mathrm{Cd}$ uptake by vegetables from soil is also higher at a low $\mathrm{pH}$ of soil $[14,16]$.

The concentrations of $\mathrm{Cd}$ in vegetable and soil samples are presented in Fig. 1. The concentration of $\mathrm{Cd}$ in vegetables was recorded at below detection limit in almost all samples except in onions at Mlalo $(0.09 \mu \mathrm{g} / \mathrm{g}-\mathrm{dw})$ and tomatoes at Montisory $(0.09 \mu \mathrm{g} / \mathrm{g}-\mathrm{dw})$, both being recorded at above the FAO/WHO [17] permissible limit of $0.05 \mu \mathrm{g} / \mathrm{g}$. Cd contaminated vegetables are known to result in bone fracture, diarrhea, stomach pains and severe vomiting, reproductive failure, damage of central nervous system and DNA, in addition to cancer development [18]. In the soil, Cd was recorded at below the TZS [19] permissible limit of $1.0 \mu \mathrm{g} / \mathrm{g}$ in all sampled locations. This is because $\mathrm{Cd}$ is a mobile element, easily absorbed by roots and transported to shoots where it is uniformly distributed in plant [20].

Results for Cd from the present study were similar to results reported from studies conducted in non-polluted areas that recorded $\mathrm{Cd}$ from non-detected levels to $1.1 \mu \mathrm{g} / \mathrm{g}-\mathrm{dw}$ in cauliflower, cabbage and tomatoes, with respective concentration in soil of $0.014 \mu \mathrm{g} / \mathrm{g}-\mathrm{dw}$ to $0.721 \mu \mathrm{g} / \mathrm{g}-\mathrm{dw}$ [21]. Al-Charani et al. [16] found Cd levels in cauliflowers (0.0559 - $0.6185 \mu \mathrm{g} / \mathrm{g}-\mathrm{dw})$, cabbages $(0.0401-0.4372 \mu \mathrm{g} / \mathrm{g}-\mathrm{dw})$, tomatoes $(0.1731-0.8190 \mu \mathrm{g} / \mathrm{g}-\mathrm{dw})$ and carrots $(0.0594$ $-0.2798 \mu \mathrm{g} / \mathrm{g}-\mathrm{dw}$. Abbas et al. [21] reported mean levels of $0.079 \mu \mathrm{g}-\mathrm{Cd} / \mathrm{g}-\mathrm{dw}$ in onions and $0.049 \mu \mathrm{g}-\mathrm{Cd} / \mathrm{g}-\mathrm{dw}$ to 0.075 
$\mu \mathrm{g}-\mathrm{Cd} / \mathrm{g}-\mathrm{dw}$ in cabbage, cauliflower and tomato.

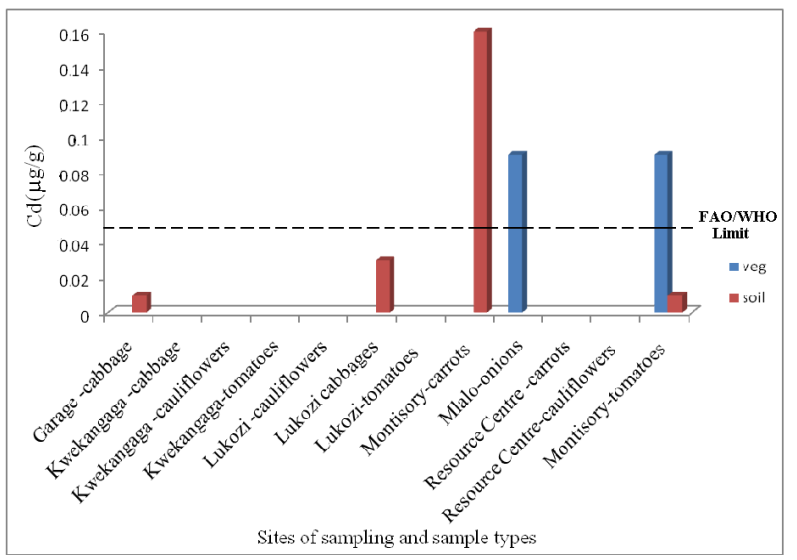

Figure 1. Cadmium levels in vegetables and soils from Lushoto.

\subsubsection{Copper}

The concentrations of $\mathrm{Cu}$ in vegetables and soils at the different sites of Lushoto are presented in Fig. 2. The concentration of $\mathrm{Cu}$ in all vegetables and tomatoes ranged between $0.04 \mu \mathrm{g} / \mathrm{g}-\mathrm{dw}$ in cabbages and $3.7 \mu \mathrm{g} / \mathrm{g}-\mathrm{dw}$ in carrots with the mean concentration being $0.794 \mu \mathrm{g} / \mathrm{g}-\mathrm{dw}$. All vegetables and tomatoes recorded $\mathrm{Cr}$ levels below the permissible limit of $5 \mu \mathrm{g} / \mathrm{g}$ [17] thus falling within the safety limits. Consumption of these vegetables will not result to copper related health problems. In the respective soils levels of $\mathrm{Cu}$ ranged between $1.69 \mu \mathrm{g} / \mathrm{g}-\mathrm{dw}$ and $0.05 \mu \mathrm{g} / \mathrm{g}$-dw. The mean concentration recorded $(0.80 \pm 0.673 \mu \mathrm{g} / \mathrm{g}$-dw) was well below the TZS [19] permissible limit $(200 \mu \mathrm{g} / \mathrm{g})$. Unpaired t-test indicated the concentration in vegetables and soil statistically not showing significant differences $(\mathrm{t}=|-0.154|, \mathrm{P}$ $=0.988$ ).

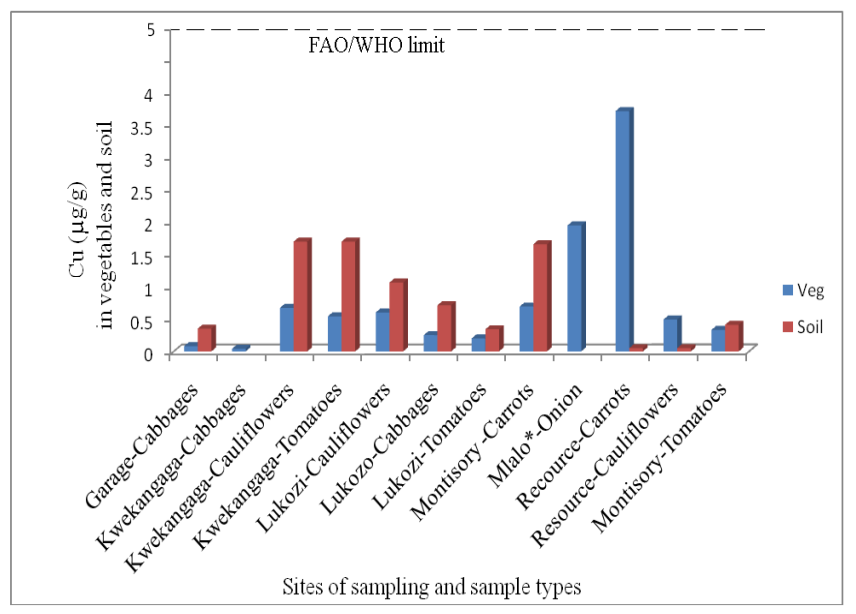

Figure 2. Copper levels in vegetables and soils in Lushoto

Studies $[12,22]$ also recorded the concentration of $\mathrm{Cu}$ at below the FAO/WHO permissible limit in cabbages. The availability of $\mathrm{Cu}^{2+}$ in soil is linked with soil $\mathrm{pH}$. Malik et al. [23] has found that increased soil $\mathrm{pH}$ may also reduce the availability of $\mathrm{Cu}^{2+}$ to vegetables through increased adsorption at cation exchange sites.

\subsubsection{Chromium}

The concentrations of $\mathrm{Cr}$ in the vegetables and tomatoes were between $0.44 \mu \mathrm{g} / \mathrm{g}$-dw and $20.00 \mu \mathrm{g} / \mathrm{g}$-dw (Fig. 3). The mean concentration in cabbages from Lukozi and carrots from Resource Centre and Montisory-Sister sites were above the FAO/WHO [24] permissible limit of $0.05 \mu \mathrm{g} / \mathrm{g}$. Consumption of the affected vegetables will certainly result to health consequences which include kidney and liver damage, skin rashes, stomach upset and ulcer, respiratory problems and lung cancer and alteration of genetic materials. The respective soils showed levels of $\mathrm{Cr}$ between $0.02 \mu \mathrm{g} / \mathrm{g}-\mathrm{dw}$ and $(0.35 \mu \mathrm{g} / \mathrm{g}-\mathrm{dw})$, values below the TZS [19] permissible limit of $100 \mu \mathrm{g} / \mathrm{g}$ with a mean concentration recorded of $0.074 \mu \mathrm{g} / \mathrm{g}-\mathrm{dw}$. Unpaired t-test of the concentration of $\mathrm{Cr}$ in vegetables and soils indicated no significant differences $(\mathrm{t}=1.62, \mathrm{P}=0.121)$.

Variation of soil $\mathrm{pH}$ between 5.65 and 7.21 could have facilitated $\mathrm{Cr}$ solubility and availability for absorption by vegetables $[14,25)$.

Studies by Alamin et al. [26] indicated higher $\mathrm{Cr}$ concentrations in cabbages $(1.39 \mu \mathrm{g} / \mathrm{g}$-dw) than in carrots $(0.35 \mu \mathrm{g} / \mathrm{g}-\mathrm{dw})$ in Libya. Banerjee et al. [27] conducted studies in polluted and non-polluted areas and recorded high concentrations of $\mathrm{Cr}$ in cauliflower $(2.45 \mu \mathrm{g} / \mathrm{g}-\mathrm{dw})$, tomato $(0.20 \mu \mathrm{g} / \mathrm{g}-\mathrm{dw})$ and cabbage $(1.35 \mu \mathrm{g} / \mathrm{g}-\mathrm{dw})$ than in their respective soils.

\subsubsection{Lead}

The concentrations of $\mathrm{Pb}$ in vegetables were recorded at below detection limit in all samples (Fig. 4) except in carrots from Montisory $(9.12 \mu \mathrm{g} / \mathrm{g}-\mathrm{dw})$, onions at Mlalo market (7.48 $\mu \mathrm{g} / \mathrm{g}-\mathrm{dw})$ and carrots at the Resource centre $(1.61 \mu \mathrm{g} / \mathrm{g}-\mathrm{dw})$. The mean concentration for these vegetables being 6.19 $\mu \mathrm{g} / \mathrm{g}$-dw, a level well above the FAO/WHO [24] permissible limit of $0.3 \mu \mathrm{g} / \mathrm{g}$. Consumption of these vegetables would certainly result in health problems.

$\mathrm{The} \mathrm{Pb}$ levels in soils from the respective locations were recorded from below detection limit at Kwekangaga to 8.45 $\mu \mathrm{g} / \mathrm{g}-\mathrm{dw}$ at the Garage location. All $\mathrm{Pb}$ levels were below the TZS [19] permissible limit of $200 \mu \mathrm{g} / \mathrm{g}$-dw.

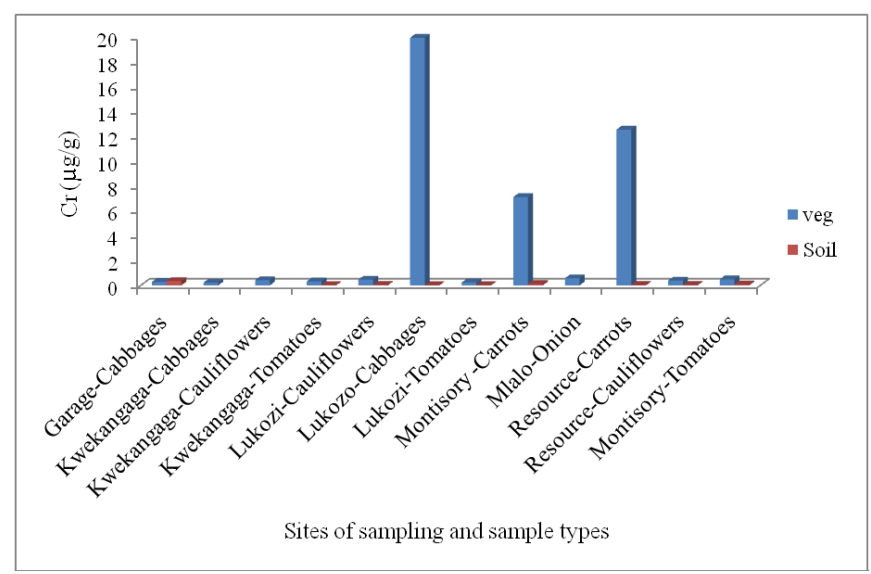

Figure 3. Chromium levels in vegetables and soils from Lushoto

Unpaired t-test statistics indicated no significant differences $(\mathrm{t}=1.43, \mathrm{P}=0.202)$. Studies by Al-Chaarani et al. [16], Abbas 
et al. [21] and Banerjee et al. [27] have also reported elevated levels of $\mathrm{Pb}$ in vegetables and tomatoes.

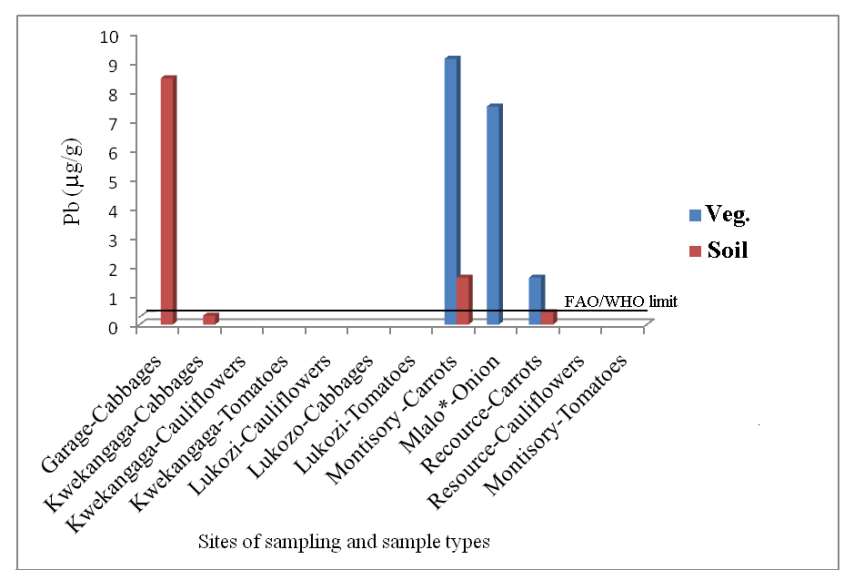

Figure 4. Lead concentrations in vegetables and soils from Lushoto

\subsubsection{Zinc}

In the present study high levels of $\mathrm{Zn}$ were recorded in vegetables and tomatoes at all locations. It ranged between $20.15 \mu \mathrm{g} / \mathrm{g}$-dw and $80.00 \mu \mathrm{g} / \mathrm{g}-\mathrm{dw}$, well above the FAO/WHO permissible limit of $5 \mu \mathrm{g} / \mathrm{g}$ [24]. The mean concentration recorded was $41.60 \mu \mathrm{g} / \mathrm{g}$-dw. Studies $[28,29]$ also reported levels of $\mathrm{Zn}$ in vegetables and tomatoes above the permissible levels of FAO/WHO. Among all heavy metals, $\mathrm{Zn}$ is the least toxic and is an essential element in the human diet as it is required to maintain the proper functioning of the immune system, normal brain activity and is fundamental in the growth and development of the foetus. Excessive $\mathrm{Zn}$ in the diet e.g. prolonged daily intake of zinc ranging at $150-450 \mathrm{mg} /$ day, is also detrimental to human health $[30,31]$.

The soil samples had $\mathrm{Zn}$ levels from 0.04 to $13.90 \mu \mathrm{g} / \mathrm{g}-\mathrm{dw}$ that were lower than in the respective vegetables and lower than the TZS [19] limit. The mean concentration recorded was $6.70 \mu \mathrm{g} / \mathrm{g}$-dw. Unpaired t-test indicated the concentration of $\mathrm{Zn}$ in vegetables and soil statistically exhibited significant differences $(t=6.33, P=0.001)$. Since there was no major industry existing in the study areas, it was assumed that the sources of $\mathrm{Zn}$ were probably from rubber from motor vehicle tires exacerbated by poor road surfaces in the area and the waste-lubricating oils in which $\mathrm{Zn}$ is found as part of many additives such as zinc dithiophosphates [32]

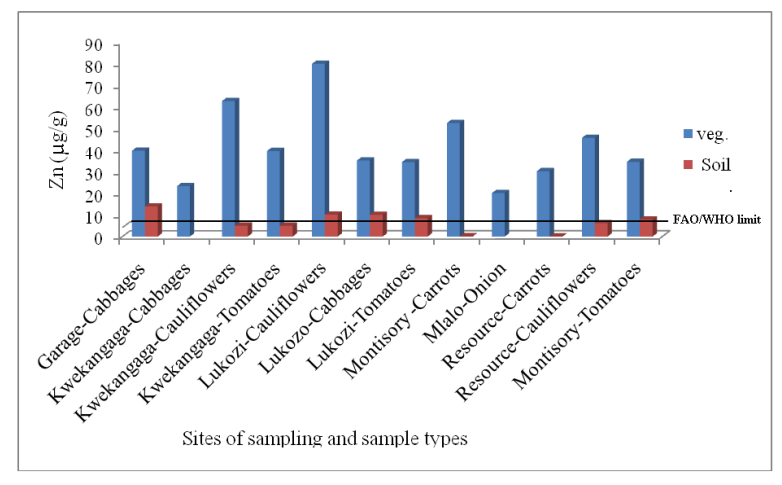

Figure 5. Zinc levels in vegetables and soils from Lushoto

\subsection{Bioconcentration Factors (BCF) of Heavy Metals}

The calculated BCF for the heavy metals in Lushoto district produce are presented in Table 2. The BCF of above 1.0 indicates higher uptake of heavy metals in vegetables than in the soil. Any area which recorded BCF below 1.0 indicates high heavy metal concentration in soil in relation to levels in vegetables [4] and therefore low uptake of heavy metals to vegetables. Several reports have dealt with $\mathrm{BCF}$ determinations for vegetables [33, 34].

Table 2. Bioconcentration Factor (BCF) for samples from Lushoto.

\begin{tabular}{|c|c|c|c|c|c|}
\hline \multicolumn{6}{|c|}{ BCF for heavy metals } \\
\hline Location (vegetables) & $\mathbf{C u}$ & $\mathrm{Cr}$ & Zn & Cd & $\mathbf{P b}$ \\
\hline Garage (Cabbages) & 0.23 & 0.80 & 2.86 & * & $*$ \\
\hline $\begin{array}{l}\text { Kwekangaga } \\
\text { (Cabbages-w) }\end{array}$ & $* *$ & $* *$ & $* *$ & $* *$ & $* *$ \\
\hline $\begin{array}{l}\text { Kwekangaga } \\
\text { (Cauliflowers) }\end{array}$ & 0.40 & $*$ & 12.48 & $*$ & $*$ \\
\hline $\begin{array}{l}\text { Kwekangaga } \\
\text { (Tomatoes) }\end{array}$ & 0.32 & 10.67 & 7.89 & $*$ & $*$ \\
\hline $\begin{array}{l}\text { Lukozi-Jegeta } \\
\text { (Cauliflowers) }\end{array}$ & 0.57 & 9.20 & 7.89 & $*$ & $*$ \\
\hline $\begin{array}{l}\text { Lukozi-Jegeta } \\
\text { (Cabbages) }\end{array}$ & 0.35 & 9.98 & 3.49 & $*$ & $*$ \\
\hline Lukozi (Tomatoes) & 0.59 & 11.5 & 4.05 & $*$ & $*$ \\
\hline $\begin{array}{l}\text { Montisory-Sisters } \\
\text { (Carrots) }\end{array}$ & 0.42 & 64.7 & 478.18 & * & 5.66 \\
\hline Mlalo market (Onions) & $* *$ & $* *$ & $* *$ & $* *$ & $* *$ \\
\hline $\begin{array}{l}\text { Recource Centre } \\
\text { (Carrots) }\end{array}$ & 74 & 314 & 757.5 & * & 3.83 \\
\hline $\begin{array}{l}\text { Resource Centre } \\
\text { (Cauliflowers) }\end{array}$ & 9.8 & 9.50 & 7.36 & * & $*$ \\
\hline Montisory (Tomatoes) & 0.81 & 5.44 & 4.37 & 9 & $*$ \\
\hline
\end{tabular}

* The ratio of soil and vegetable not calculated, one of the results was below detection limit

** Areas where soil was not sampled.

The BCFs of $\mathrm{Cr}, \mathrm{Zn}, \mathrm{Cd}$ and $\mathrm{Pb}$ for all vegetables and at all locations were found to be, in general, above one (1.0) except for $\mathrm{Cr}$ (cabbages) at the Garage site. $\mathrm{Cu}$ was recorded with $\mathrm{BCF}$ below 1.0 at all locations except at the Resource Centre for carrots and cauliflowers (table 2). Such high BCF values suggest that these leafy vegetables and tomatoes should not be eaten raw.

\section{Conclusion}

Lushoto soils had $\mathrm{pH}$ recorded as mildly acidic (5.53) to mildly alkaline (7.22). Such soils were contributing to increased heavy metal solubility and their uptake into vegetables and tomatoes being grown there. The concentration of heavy metals $\mathrm{Cu}, \mathrm{Cr}, \mathrm{Cd}, \mathrm{Pb}$ and $\mathrm{Zn}$ in the soil were recorded as below the TZS [19] permissible limits for these metals. The levels of these heavy metals in vegetables varied from below detection limits to well above of the FAO/WHO permissible limits in foods [24]. The mean concentrations of these heavy metals in vegetables and tomatoes were also observed to be above the FAO/WHO limits [24] and were therefore concluded as not safe for human consumption. $\mathrm{Cu}$ was the only heavy metal detected at levels allowable for human consumption. 
The overall concentration of heavy metals in vegetables showed that $\mathrm{Zn}$ was present at the highest concentration as compared to the other metals. Statistically it was observed that there was significant difference for $\mathrm{Zn}$ content between the studied vegetables and soils even though it was noted that most of the study area had no industrial locations or activities. The Lushoto study area recorded levels of heavy metals above the FAO/WHO permissible limits in vegetables and foods [24] and below the TZS permissible limits in soil [19].

The $\mathrm{BCF}$ for $\mathrm{Cr}, \mathrm{Pb}, \mathrm{Cd}$ and $\mathrm{Zn}$ in examined vegetables and tomatoes except for cabbages at the Garage site were found to be above 1 indicating high uptake of heavy metals in the vegetables and tomatoes from the soil. At $80 \%$ of the sites, $\mathrm{Cu}$ had a BCF lower than 1 indicating that $\mathrm{Cu}$ was more abundant in the soil compared to the vegetables. These results suggest that cabbages, cauliflowers, onions, tomatoes and carrots from Lushoto district are not safe for consumption in their raw state.

\section{References}

[1] Adekunle, I.M., Olorundare, O., and Nwange, C., Assessments of lead levels and daily intakes from green leafy vegetables of southwest Nigeria. Nutrition and Food Science 39, 2009, p. 413-422.

[2] Soudek, P., Kotyza, J., Ivana, Lenikusová., Šárka, Petrová., Benešová, D., and Tomáš, K., Accumulation of heavy metals in hydroponically cultivated garlic (Allium sativum L.), onion (Allium cepa L.), leek (Allium porrum L.) and chive (Allium schoenoprasum L.) J. Food, Agr. and Environ. 7, 2009, p. 761-769.

[3] Pandey, J., and Pandey, U., Accumulation of heavy metals in dietary vegetables and cultivated soil horizon in organic farming system in relation to atmospheric deposition in a seasonally dry tropical region of India. Environ. Monit. Assess. 148, 2009, p. 61-74.

[4] Siddiqui, M.F., Cadmium induced renal toxicity in male rats. Journal of Medicine 15, 2010, p. 93-96.

[5] Ministry of Agriculture and Food Security. Horticulture development in Tanzania 2002, Ministry of Agriculture, Tanzania.

[6] De Putter, H., Van K, M.J and De V, C.L.M., Overview of the vegetable sector in Tanzania, Report No.1. 2007.

[7] Bahemuka, T.E., and Mubofu, E.B., Heavy metals in edible green vegetables grown along the sites of the Sinza and Msimbazi rivers in Dar es Salaam, Tanzania. Food Chem. 66, 1999, p. 63-66.

[8] Othman, O.C., Heavy metals in green vegetables and soils from vegetable gardens in Dar es Salaam, Tanzania. Tanz. J. Sci. 27, 2001, p. 37-48.

[9] Kauleni, A., Bioaccumulation of heavy metals from irrigation water in Vigna Uluguiculata and other vegetables grown in Dar es Salaam, MSc(Chemistry) Dissertation, 2001, University of Dar es Salaam, Chemistry Department.

[10] Kilimia, F.Z.K., A comparative study of heavy metal pollutant levels in vegetables grown under urban and rural conditions in Dar es salaam, Tanzania. 2001, MSc(Chemistry) Dissertation, University of Dar es Salaam, Chemistry Department.
[11] Mwijage, E.F., Mobilization of selected chemical constituents into the human chain via horticultural produce grown in Dar es Salaam 2002 MSc(Chemistry) Thesis, University of Dar es salaam, Chemistry Department.

[12] Chove, B. E., Ballegu, W.R., and Chove, L.M., Copper and lead levels in two popular leafy vegetables grown around Morogoro Municipality, Tanzania. Tanz. Health Res. Bull. 8, 2006, p. 1.

[13] Kibassa, D. Kimaro, A. A. and Shemdoe, R. S. Heavy metals concentrations in selected areas used for urban agriculture in Dar es Salaam, Tanzania. Sci. Res. Essays 8(27), 2013, p. 1296-1303.

[14] Akinola, M.O., Njoku, K.L., and Ekeifo, B.E., Determination of lead, cadmium and chromium in the tissue of an ecconomically important plant grown around a textile industry at Ibeshe, Ikorodu Area of Lagos State, Nigeria. Advances in Environmental Biology 2, 2008, p. 25-30.

[15] Kothari, C.R., Research methodology, method and techniques. $2^{\text {nd }}$ Edn, 2004 New age international (P) Ltd, New Delhi Vikas, India.

[16] Al-Chaarani, N., El-Nakat, J.H., Obeid, P.J., and Aouad S., Measurement of levels of heavy metal contamination in vegetables grown and sold in selected areas in Lebanon. Jordan J. of Chem. 4, 2009, p. 303-315.

[17] FAO/WHO, CODEX ALIMENTARIUS International Food Standards CODEX STAN-193. Codex Alimentarius commission, WHO/FAO, 1995.

[18] Oti, W.J.O. and Nwabue, F.I. Heavy metals effect due to contamination of vegetables from Enyigba lead mine in Ebonyi state, Nigeria. Environment and Pollution 2(1), 2013, p. 19-26.

[19] TZS 972:2007 Soil quality - Limits for soil contaminants in habitat and agriculture. 2007, Tanzania Bureau of Standards (TBS), Dar es Salaam.

[20] Sêkara, A., Poniedziaek, M., Ciura, J., and Jêdrszczyk, E., Cadmium and Lead Accumulation and Distribution in the Organs of Nine Crops: Implications for Phytoremediation. Polish Journal of Environmental Studies 14(4), 2005, p. 509 -516 .

[21] Abbas, M., Parveen, Z., Iqbal, M., Riazuddin, M., Iqbal, S., Ahmed, M. and Bhutto, R., Monitoring of toxic metals (cadmium, lead, arsenic and mercury) in vegetables of Sindh, Pakistan. Kathmandu University Journal of Science, Engineering and Technology 6, 2010, p. 60-65.

[22] Farooq, M., Anwar, F. and Rashid, U., Appraisal of heavy metal contents in different vegetables grown in the vicinity of an industrial area. Pakistan J. Bot. 40, 2008, p. 2099-2106.

[23] Malik, R.N., Husain, S.Z., and Nazir, I., Heavy metal contamination and accumulation in soil and wild plant species from industrial area of Islamabad. Pakistan J. of Bot. 42(1), 2010, p. 291-301.

[24] FAO/WHO, CODEX ALIMENTARIUS International Food Standards CODEX STAN-179. Codex Alimentarius commission, WHO/FAO, 2003.

[25] Akan, J.C., Abdulrahman, F.I., Sodipo, O.A., and Lange, A.G., Physicochemical parameters in soil and vegetable samples from Gongulon Agricopperltural Site, Maiduguri, Borno State, Nigeria. Journal of American Science 6, 2010, p. 7-12. 
[26] Alamin, M.B., Mhapes, A.A., Bejey, A.M., Sadek, A., Atweer, R.H., Dubali, K., and Saad, D.M., Determination of essential and toxic elements in Libyan foodstuff using instrumental neutron activation analysis (INAA). Journal of Radioanalytical and Nuclear Chemistry 271, 2007, p. 247-250.

[27] Banerjee, D., Bairagi, H., Mukhopadhyay, S., Pal, A., Bera, D., and Ray, L., Heavy metal contamination in fruits and vegetables in two districts of West Bengal, India. Electronic $J$. Environmental, Agricultural and Food Chemistry 9(9), 2010, p. $1423-1432$

[28] Bosiacki, M., and Tyksiñski, W., Lead, zinc, iron and manganese content in edible parts of some fresh vegetables sold on markets in Pozincañ. Journal of Elementol. 14, 2009, p. $13-22$.

[29] Kirmani, M.Z., Sheikh, M., Farah, N., Iftikhar, I.N., and Erum, Z., Determination of some toxic and essential trace metals in some medicinal and edible plants of karachi city. Journal of Basic and Applied Sciences. 7, 2011, p. 89-95.
[30] NIH, Zinc - Fact sheet for Health Professionals, Office of Dietary Supplements, National Institute of Health, USA. (http://ods.od.nih.gov/factsheets/Zinc-HealthProfessional/)

[31] Johnson, A.R., Munoz, A., Gottlieb, J.L. and Jarrard, D.F. High dose zinc increases hospital admissions due to genitourinary complications. J Urol 177, 2007, p.639-643.

[32] Qasem, M., Kamal, A., and Moman, I., Contamination of roadside soil, plants, and air with heavy metals in Jordan, A comparative Study. Turk. J. Chem. 23, 1999, p. 209-220.

[33] Liu, W.X., Li, H.H., Li, S.R. and Wang, Y.W. Heavy metal accumulation of edible vegetables cultivated in agricultural soil in the suburb of Zhengzhou City, People's Republic of China. Bulletin of Environmental. Contamination and Toxicology, 76, 2006, p.163-170.

[34] Yadav, A., Yadav, P.K. and Shukla D.N. Investigation of heavy metal status in soil and vegetables grown in urban areas of Allahabad, Uttar Pradesh, India. International Journal of Scientific and Research Publications, 3(9), 2013, p.1 - 7. 